\title{
Nitrogen form and mycorrhizal inoculation amount and timing affect flavonol biosynthesis in onion (Allium cepa $\mathrm{L}$.)
}

\author{
Mohanna Mollavali ${ }^{1,2} \cdot$ Henrike Perner $^{2} \cdot$ Sascha Rohn $^{3} \cdot$ Peer Riehle $^{3}$ • \\ Franziska S. Hanschen ${ }^{2}$ • Dietmar Schwarz ${ }^{2}$ (D)
}

Received: 23 January 2017 / Accepted: 31 August 2017 / Published online: 26 September 2017

(C) The Author(s) 2017. This article is an open access publication

\begin{abstract}
Mycorrhizal symbiosis is known to be the most prevalent form of fungal symbiosis with plants. Although some studies focus on the importance of mycorrhizal symbiosis for enhanced flavonoids in the host plants, a comprehensive understanding of the relationship still is lacking. Therefore, we studied the effects of mycorrhizal inoculation of onions (Allium cepa L.) regarding flavonol concentration and the genes involved in flavonol biosynthesis when different forms of nitrogen were supplied. We hypothesized that mycorrhizal inoculation can act as a biotic stress and might lead to an increase in flavonols and expression of related genes. The three main quercetin compounds [quercetin-3,4'di- $O-\beta$-D-glucoside (QDG), quercetin-4'- $O$ - $\beta$-D-glucoside (QMG), and isorhamnetin-4'-O- $\beta$-D-glucoside (IMG)] of onion bulbs were identified and analyzed after inoculating with increasing amounts of mycorrhizal inocula at two time points and supplying either predominantly $\mathrm{NO}_{3}{ }^{-}$or $\mathrm{NH}_{4}{ }^{+}$nitrogen. We also quantified plant dry mass, nutrient element uptake, chalcone synthase (CHS), flavonol synthase (FLS), and phenyl alanine lyase $(P A L)$ gene expression as key enzymes for flavonol biosynthesis. Inoculation with arbuscular mycorrhizal fungi (highest amount) and colonization at late development stages (bulb growth) increased QDG and QMG concentrations if plants were additionally supplied with
\end{abstract}

Dietmar Schwarz

schwarz@igzev.de

1 Vegetable Physiology Laboratory, Department of Horticulture, University of Tabriz, Tabriz, Iran

2 Leibniz Institute for Vegetable and Ornamental Crops, Theodor-Echtermeyer-Weg 1, 14979 Großbeeren, Germany

3 Institute of Food Chemistry, Hamburg School of Food Science, University Hamburg, Grindelallee 117, 20146 Hamburg, Germany predominantly $\mathrm{NH}_{4}{ }^{+}$. No differences were observed in the IMG content. RNA accumulation of CHS, FLS, and PAL was affected by the stage of the mycorrhizal symbiosis and the nitrogen form. Accumulation of flavonols was not correlated, however, with either the percentage of myorrhization or the abundance of transcripts of flavonoid biosynthesis genes. We found that in plants at late developmental stages, RNA accumulation as a reflection of a current physiological situation does not necessarily correspond with the content of metabolites that accumulate over a long period. Our findings suggest that nitrogen form can be an important factor determining mycorrhizal development and that both nitrogen form and mycorrhizas interact to influence flavonol biosynthesis.

Keywords Ammonium $\cdot$ Chalcone synthase $\cdot$ Flavonol synthase $\cdot$ Nitrate $\cdot$ Quercetin $\cdot$ Phenyl alanine lyase

\section{Introduction}

Onion (Allium cepa L.) is one of the world's oldest and most widely cultivated vegetables which has great economic importance, particularly in Asia and Europe (Griffiths et al. 2002). Previous studies on the health benefits of onion reported that bulbs are rich in two main groups of chemical compounds: $S$ alk(en)yl-L-cysteine sulfoxides and flavonoids (Crozier et al. 1997; Price et al. 1997; Griffiths et al. 2002). Flavonoids are a diverse class of polyphenolic compounds. In onion, the flavonols quercetin, isorhamnetin, and kaempferol derivatives are present; it is a subgroup of flavonoids (Bilyk et al. 1984). They typically occur glycosylated with sugars such as glucose. The main flavonols in onion have been determined as quercetin$3,4^{\prime}$-di- $O$ - $\beta$-D-glucoside (QDG) and quercetin-4'- $O$ - $\beta$-D-glucoside (QMG), both making up to $80-85 \%$ of the total flavonoid content (Price and Rhodes 1997; Rhodes and Price 
1996). Flavonoids have received considerable attention based on their many functions in plants, including protection against ultraviolet radiation, regulation of auxin transport, and modulation of flower color (Buer et al. 2010). They also may act as signaling molecules involved in plant defense mechanisms against fungal pathogen attack or directly as plant defense agents (Bi et al. 2007; Mandal et al. 2010). Chalcone synthase (CHS) is a key enzyme in the flavonoid biosynthesis pathway and therefore is involved with the biosynthesis of dihydroquercetin where the pathway divides into the formation of the anthocyanidin cyanidin and the flavonol quercetin. Quercetin is formed by flavonol synthase (FLS) and further transformed to the glucosides by the appropriate quercetin- 4 '$O$-glucosyl transferase and quercetin-3,4'-O-glucosyl transferase (Materska 2008; Petrussa et al. 2013).

Onions are considered as highly mycorrhiza-dependent plants because they have a low root/shoot ratio and low phosphorus inflow rates (Augé and Moore 2005). Arbuscular mycorrhizal fungi (AMF) are known to significantly influence the composition of flavonoids in onions and other plants (Ling-Lee et al. 1977; Ponce et al. 2004; Perner et al. 2008). AMF contact with host plant roots initiates defense mechanisms (Harrison and Dixon 1994; Bi et al. 2007). In consequence, production of flavonoid compounds and antioxidant enzyme activities increase (Ling-Lee et al. 1977; Devi and Reddy 2002). The CHS gene, a key enzyme in flavonoid biosynthesis, has been induced by AMF in Medicago truncatula (Bonanomi et al. 2001). The compounds derived from induction of $C H S$ expression are responsible for numerous functions, e.g., antimicrobial effect, insecticidal effect, or antioxidant activity by transforming phytoalexins (Dao et al. 2011). However, it is not clear if the enhancement of flavonoid biosynthesis by AMF is a temporary or a persistent effect.

Nitrogen supply affects bulb yield, bulb grade, firmness, maturity, and storability of onions (Charron et al. 2001; Mozumder et al. 2007). Moreover, nitrogen deficiency and nitrogen form can affect the accumulation of secondary metabolites as expressed by the carbon/nutrient balance hypothesis (Herms and Matson 1992; Scheible et al. 2004; Nguyen and Niemeyer 2008). It postulates that the status of carbon and nitrogen of plants controls the concentrations of secondary metabolites (Hamilton et al. 2001). It has been shown that nutrient stress, such as nitrogen deficiency, leads to an increase in flavonoid production in apple (Malus domestica) (Awad and de Jager, 2002, Strissel et al. 2005), Labisia pumila (Ibrahim et al. 2012), and leaves of mature tomatoes (Solanum lycopersicum) (Stewart et al. 2001). Furthermore, nutrient stress resulted in the expression of flavonoid pathway regulators in Arabidopsis thaliana (Lea et al. 2007). In connection with AMF colonization, predominant $\mathrm{NH}_{4}{ }^{+}$nutrition increased the QMG concentration in onion bulbs while predominant $\mathrm{NO}_{3}{ }^{-}$nutrition increased the QDG concentration when Allium roots were highly colonized (Perner et al. 2008).
Measurement of mRNAs of the key enzymes of flavonoid biosynthesis, phenylalanine ammonium lyase (PAL), and CHS, in the root cells of Phaseolus vulgaris showed increased accumulation of the enzymes in roots colonized with AMF (Kristopher and Anderson 1996). Taken together, it can be concluded that nitrogen deficiency and AMF root colonization cause an increase of flavonoid production.

For the present study, we hypothesized that AMF colonization can act as a biotic stress and consequently enhance flavonols as a defense mechanism, as well as inducing expression of responsible genes involved in flavonol biosynthesis. To test this hypothesis, we analyzed three main flavonols and the expressions of three key genes ( $P A L, C H S$, and $F L S$ ) triggering flavonol biosynthesis in onions. Different time points after AMF inoculation were examined in order to avoid that the induction time was missed or that plant and fungi are habituated to the symbiosis. Nitrogen supply affects AMF colonization of the host plant through direct effects involving morphological changes in AMF and indirect effects by reduced $\mathrm{C}$ allocation from plant to fungus (Blanke et al. 2005, Olsson et al. 2005). Moreover, different nitrogen forms have an impact on the flavonol concentration (Fallovo et al. 2011). So, we also tested whether even low concentrations of AMF inoculum induce and increase flavonol concentration in order to determine if such a mycorrhizal effect would be persistent. Therefore, in the present experiments, the effects on the flavonol profile and on key enzymes in the flavonol biosynthesis pathway in onion of different inoculum concentrations, different times of inoculation, and different nitrogen forms were investigated. Because the onion variety "Stuttgarter Riesen" has high total flavonol content (unpublished data) versus other cultivars (Beesk et al. 2010) and frequently is used in European horticultural practice, we selected this cultivar for our experiment.

\section{Material and methods}

\section{Onion cultivation and treatments}

A pot experiment with eight onion sets per pot was carried out from 22 April till 18 September 2013 in greenhouse facilities at Großbeeren, Germany (long. $13^{\circ} 20^{\prime} \mathrm{E}$; lat. $51^{\circ} 22^{\prime} \mathrm{N}$ ). The experiment was arranged in a completely randomized design with three fully crossed factors and six replications. The first factor consisted of arbuscular mycorrhizal fungi (volume fraction of $0,0.3$, and $3 \%$ ), the second factor of two inoculation dates ( 0 and 65 days after sowing), and the third factor of two nitrogen supply forms $\left(95 \% \mathrm{NO}_{3}{ }^{-} / 5 \% \mathrm{NH}_{4}{ }^{+}\right.$and $25 \% \mathrm{NO}_{3}{ }^{-} /$ $75 \% \mathrm{NH}_{4}^{+}$). Onion seeds (A. cepa, cv. Stuttgarter Riesen) were suspended in $10 \%$ aqueous $\mathrm{H}_{2} \mathrm{O}_{2}$ for 10 min to sterilize the surface. Subsequently, they were washed three times with distilled water, moistened with $\mathrm{CaSO}_{4}$ solution, and sown directly into pots $(\varnothing=19 \mathrm{~cm}, 2.3 \mathrm{~L})$ filled with sterilized 
quartz sand (particle size 0.5-1 mm; Ottendorf-Okrilla $\mathrm{GmbH}$, Lausnitz, Germany). Before using, the quartz sand was sterilized by heating for 2 days at $95^{\circ} \mathrm{C}$ and afterwards was cooled. A commercial AMF inoculum (INOQ GmbH, Schnega, Germany) comprising Funneliformis mosseae and Rhizophagus irregularis (as identified by the company) was equally mixed with the quartz sand at the previously described volume fractions. Sterilized inoculum (autoclaved at $121{ }^{\circ} \mathrm{C}$ for $20 \mathrm{~min}$ ) was applied likewise at volume fractions of 3 and $2.7 \%$ to the 0 and $0.3 \%$ treatments, respectively. In this way, all treatments had comparable inoculum amounts totalling $3 \%$. In addition, the liquid of non-sterilized inoculum was filtered before sterilization $(589 / 3$ blue ribbon paper filter, Schleicher and Schuell Bioscience GmbH, Dassel, Germany) and added to the appropriate pots. This procedure was carried out to supply similar amounts of nutrients and microorganisms except AMF to all treatments. Half of the pots of the experiment were inoculated before seeding and the other half 65 days later, when the plants started bulbing. At the second inoculation date, all plants were thoroughly rooted and were transferred with their whole substrate into large pots $(\varnothing=26 \mathrm{~cm}, 6 \mathrm{~L})$. In total, 48 pots were inoculated with live inoculum as described above, while 24 got the same amount of sterilized inoculum.

All 72 pots were kept in a heated greenhouse for 44 days at a mean temperature of $18{ }^{\circ} \mathrm{C}$. Seedlings were watered with a fifth-strength modified Hoagland solution at $\mathrm{pH} 5.6$ (Hoagland and Arnon 1938). When the plants reached the third-leaf stage, the pots were transferred to an open-sided greenhouse. After 7 days of adaption, the fertilizer treatment started (51 days after seeding): plants were watered with a third-strength Hoagland solution. Nitrogen was supplied at two $\mathrm{NO}_{3}{ }^{-} / \mathrm{NH}_{4}{ }^{+}$ratios: $95 / 5 \%$ (predominant $\mathrm{NO}_{3}{ }^{-}$supply) or $25 / 75 \%$ (predominant $\mathrm{NH}_{4}{ }^{+}$supply). The nutrient solution contained the following: (mmol) $\mathrm{NO}_{3}{ }^{-} 7.03 / 1.85, \mathrm{NH}_{4}{ }^{+} 0.37 /$ 5.5, $\mathrm{K}^{+}$2.7, $\mathrm{PO}_{4}{ }^{3-} 0.4, \mathrm{Mg}^{2+} 1.6, \mathrm{SO}_{4}{ }^{2-} 1, \mathrm{Ca}^{2+} 3.6$, and ( $\mu \mathrm{mol}$ ) $\mathrm{Fe}^{2+} 55 \mathrm{Mn}^{3+} 2.5, \mathrm{Zn}^{2+} 0.4, \mathrm{BO}_{3}{ }^{3-} 18, \mathrm{Cu}^{2+} 0.25$, $\mathrm{MoO}_{4}{ }^{2+} 0.18, \mathrm{Cl}^{-} 8.84 / 14.41$. Nutrient solution was supplied until one-third of the added solution drained from the pots. A $\mathrm{pH}$ value of 5.6 was maintained by adding $\mathrm{NaOH}$ and MES buffer in a concentration of $2 \mathrm{mmol}$. Watering was reduced 14 days prior to harvest to let plants dry. Average air temperature in the open-sided greenhouse during this time was 21/ $17^{\circ} \mathrm{C}$ (day/night) and reached values of maximum $39^{\circ} \mathrm{C}$ and minimum $13{ }^{\circ} \mathrm{C}$. The relative humidity was on average $54 /$ $68 \%$ (day/night). The mean daily photosynthetic active radiation was $29.2 \mathrm{~mol} \mathrm{~m}^{-2}$ with a daily minimum of 6 and a maximum of $48 \mathrm{~mol} \mathrm{~m}^{-2}$.

\section{Harvest}

Plants were harvested 149 days after sowing, when $80 \%$ reached the soft neck stage. Six bulbs per pot were weighed including their dry skin to obtain total fresh mass and then were separated into two portions. Three bulbs were dried in an oven at $60^{\circ} \mathrm{C}$ and dry mass was determined after 2 days. Bulb dry mass samples were ground in a centrifugal grinder with a $0.5-\mathrm{mm}$ sieve and analyzed for total nitrogen, phosphorus, and potassium concentration. The outer skin of the remaining three bulbs was removed, and then, the bulbs were cut into small pieces. Thereafter, the samples were frozen at $-20{ }^{\circ} \mathrm{C}$ and later freeze-dried for flavonol analyses.

\section{Analyzing AM colonization and mineral element uptake}

Roots randomly gathered from the pots at the final harvest date, 149 days after sowing, were washed and cut into $10 \mathrm{~mm}$ length, then cleared with $10 \% \mathrm{KOH}$ solution incubated at $60{ }^{\circ} \mathrm{C}$ for $30 \mathrm{~min}$. Samples were acidified with $2 \mathrm{~N} \mathrm{HCl}$ for 2 min at room temperature and stained with $5 \%$ ink-acid solution for $40 \mathrm{~min}$ at $60^{\circ} \mathrm{C}$ in an oven. Thereafter, roots were rinsed a few times with tap water and were kept in $90 \%$ lactic acid overnight for destaining (Koske and Gemma 1989). Fifty root segments were put on slides and the percentage of root length colonization was determined with a microscope (Zeiss, Stemi2000, Göttingen, Germany) at $\times 50$ using the gridline intersection method (Giovannetti and Mosse 1980), modified from Perner et al. (2007). Two hundred gridline intersections were assessed per sample and the presence of arbuscules, hyphae, and vesicles was used to determine AMF colonization.

Ground bulb material was dry-ashed and dissolved in $18.5 \% \mathrm{HCl}$. Phosphorus, potassium, and nitrogen concentrations were analyzed and measured following standardized procedures we briefly describe as follows. Potassium was analyzed with an atomic absorption spectrophotometer (Perkin Elmer 3300, Überlingen, Germany), and phosphorus was analyzed photometrically with an EPOS-Analyzer 5060 (Eppendorf, Hamburg, Germany). Nitrogen was determined after dry oxidation by the Dumas method (ElementarVario EL, Hanau, Germany). Contents of mineral elements analyzed were calculated by multiplying mineral element concentration by the bulb dry mass.

\section{Flavonol analyses using HPLC-DAD}

The flavonoid profiles of the three major flavonols QDG, QMG, and isorhamnetin-4'-O- $\beta$-D-glucoside (IMG) were analyzed. High-performance liquid chromatography with diodearray detection (HPLC-DAD) analysis of the flavonols was performed as described by Beesk et al. (2010), with slight modifications. For the analysis of onion bulbs, $2.5 \mathrm{~g}$ of lyophilized, powdered onion samples was extracted with $50 \mathrm{~mL}$ aqueous methanol (volume faction of $70 \%$ ) for $30 \mathrm{~min}$ under continuous stirring. After a filtration step (Whatman filter, $\varnothing 150 \mathrm{~mm}, 597 \frac{1}{2}$ ), $4 \mathrm{~mL}$ of the filtrate was dried under a gentle stream of nitrogen, subsequently diluted with $2 \mathrm{~mL}$ of water, 
and loaded onto a solid phase extraction column (Chromabond PA, $6 \mathrm{ml}, 500 \mathrm{mg}$, Macherey-Nagel, Germany). The column was washed with $10 \mathrm{~mL}$ of water to remove sugars and other water-soluble compounds. The flavonols were eluted with $10 \mathrm{~mL}$ of a methanol/water/acetic acid mixture (volume fraction of 90:5:5). This dilution was used for the HPLC-DAD analysis (Smartline series system from Knauer GmbH, Berlin, Germany). The LPG (low pressure gradient) chromatography consisted of a Smartline manager (5050 series), pump (1000 series), autosampler (3950 series), and diode array detector (2600 series). The system was controlled by ClarityChrom 3.0 software (Knauer $\mathrm{GmbH}$, Berlin, Germany). A binary gradient system based on Riehle et al. (2013) with eluent (A) $0.1 \%$ formic acid in water, eluent (B) $0.1 \%$ formic acid in acetonitrile was conducted on a Luna ${ }^{\circledR} 5 \mu \mathrm{m} \mathrm{C18} 100 \AA(150 \times 3.00 \mathrm{~mm})$ column equipped with a $\mathrm{C} 18$ security guard $(4 \times 3.00 \mathrm{~mm})$, both from Phenomenex Inc. (Aschaffenburg, Germany). Gradient elution was used for methanolic SPE eluates: $5 \% \mathrm{~B}$ isocratic (0-2 min), 5-10\% B (2-6 min), 10-30\% B (6-45 min), 3095\% B (45-55 min), 95\% B isocratic (55-60 min), 95-5\% B (60-65 $\mathrm{min})$, and $5 \%$ isocratic $(65-75 \mathrm{~min})$. The flow rate was $0.6 \mathrm{~mL} / \mathrm{min}$ and the column temperature was $21^{\circ} \mathrm{C}$. The detection was performed simultaneously at 280,325 , and $365 \mathrm{~nm}$.

\section{$C H S, F L S$, and $P A L$ gene expression analyses}

Samples were taken 7 days after the second inoculation (65 days after seeding) because gene expression of chalcone, flavonol synthase, and PAL is detectable at the beginning of the formation of the symbiosis (Bonanomi et al. 2001). One bulb from each pot was harvested, immediately frozen in liquid nitrogen, and kept at $-80{ }^{\circ} \mathrm{C}$ until further analysis. Total RNA was extracted from bulb tissue derived from three replications (100 mg) with an RNeasy Plant MiniKit (QIAGEN, Hilden). First strand complementary DNA (cDNA) was synthesized from total RNA $(2 \mu \mathrm{g})$ with M-MLV reverse transcriptase (Promega, Mannheim) and oligo d(T) primer (10 mmol) according to the manufacturer's protocol. Genespecific primers were designed using the Lasergene software (DNASTAR, Madison, WI, USA) as follows:

CHS (forward): 5'-AGTGCGTGCGTGTTGTTTAT-3', CHS (reverse): 5'-GAAGCACAACGGTCTCAACA -3', $F L S$ (forward): 5'-TTTGGAAGGGAAGAAGGCCT-3', FLS (reverse): 5'-TGTGTACTCCTCGTTTGCCT-3', $P A L$ (forward): 5'-TTCTTGTACAGCATGCACTGA-3', $P A L$ (reverse): 5'-TATTCTATTAGGAACCACTGCA-3', ALL ITS1 (forward): 5'-TATGTTCCACTGGC AGGCTACTAT-3',

ALL ITS1 (reverse): 5'-TGGAAATGGTTAAC GCAGGAC-3'.
The resulting cDNA served as a template for PCR amplification. All PCRs were performed as follows: an initial denaturation of $1 \mathrm{~min}$ at $95{ }^{\circ} \mathrm{C}$ and 35 cycles of $95{ }^{\circ} \mathrm{C}$ for $30 \mathrm{~s}$, $61{ }^{\circ} \mathrm{C}(C H S 1)$ or $56{ }^{\circ} \mathrm{C}(F L S 1)$ for $30 \mathrm{~s}, 72{ }^{\circ} \mathrm{C}$ for $10 \mathrm{~s}$, and then a final 10 -min extension at $72{ }^{\circ} \mathrm{C}$. Seven microliters of PCR products was analyzed by $3 \%$ agarose gel electrophoresis. Real-time PCR (Applied Biosystems, 7500 Real-Time PCR System) was performed in a $10 \mu \mathrm{L}$ reaction volume with $200 \mathrm{nmol} / \mathrm{L}$ for each primer and $2 \times$ SensiMix SYBR LowROX (Bioline, Luckenwalde, Germany). Values represent gene transcript abundance of the three genes normalized to the reference gene ALL ITS1 derived from three independent repetitions. RT-PCR reactions were performed in a $10 \mu \mathrm{L}$ reaction mixture containing $1 \mu \mathrm{g}$ template, $5 \mu \mathrm{L}$ SYBER Green, $2 \mu \mathrm{L}$ forward primer $(200 \mathrm{nmol} / \mathrm{L}), 2 \mu \mathrm{L}$ reverse primer (200 nmol/L). All PCRs were performed as previously described.

\section{Statistical analysis}

Data were analyzed in accordance with the experimental design. The percentage root length colonized was determined for three replications and non-parametrically analyzed using Kruskal-Wallis ANOVA. Means were compared by MannWhitney $U$ test at a significance level of $\alpha=0.05$. A threeway ANOVA was used to evaluate the treatment effects for all other characteristics at a significance level of $\alpha=0.05$. Means were compared with Duncan's multiple range test. All statistical analyses were conducted with the "SPSS" computer software package (v. 18.0, SPSS, IBM, USA).

\section{Results}

\section{Mycorrhizal colonization}

All inoculated plants were colonized with AMF except those that received a low amount $(0.3 v / v \%)$ of inoculum at predominant $\mathrm{NH}_{4}{ }^{+}$supply (Table 1). The percentage root length colonized ranged from 0 to $74.7 \%$ among the treatments. The highest percentage root length colonized was found with first inoculation (0 day), highest amount of inoculum (3\%), and predominant $\mathrm{NO}_{3}{ }^{-}$. The three factors, nitrogen form and amount and time of inoculation, however, seem to interact in their effects on mycorrhizal colonization. Plants fertilized predominantly with $\mathrm{NO}_{3}{ }^{-}$showed a significantly higher percentage root length colonized than those fertilized predominantly with $\mathrm{NH}_{4}{ }^{+}$and with increasing amounts of AMF inoculum. Percentage root length colonized was 0 or low in those pots treated with predominant $\mathrm{NH}_{4}{ }^{+}$independent of the amount and date of live inoculum supplied. Roots of all noninoculated plants remained free of AMF colonization. 
Table 1 Effect of mycorrhizal inoculation (AMF), date of inoculation (days after seeding), and nitrogen $(\mathrm{N})$ form on the percentage root-length colonized (PRC) in onion plants ( $c v$. Stuttgarter Riesen) analyzed after a growing period of 149 days in an orthogonal experimental scheme with six replications. Means \pm standard deviation $(\mathrm{SD})$ followed by the same letter do not differ significantly according to Mann-Whitney $U$ test. Probability levels written in italics indicate significant differences at a significance level of $\alpha=0.05$

\begin{tabular}{|c|c|c|c|c|}
\hline $\operatorname{AMF}(v / v \%)$ & Date (days) & $\mathrm{N}$ form & $\operatorname{PRC}(\%)$ & Probability level \\
\hline 0 & & & $0 \pm 0 \mathrm{c}$ & 0.007 (0 vs. 0.3$)$ \\
\hline 0.3 & & & $19.04 \pm 8.3 \mathrm{~b}$ & $<0.001(0$ vs. 3$)$ \\
\hline \multirow[t]{5}{*}{3.0} & & & $31.88 \pm 9.2 \mathrm{a}$ & 0.013 (0.3 vs. 3$)$ \\
\hline & 0 & & $21.23 \pm 7.4$ & 0.502 \\
\hline & 65 & & $12.71 \pm 1.3$ & \\
\hline & & $\mathrm{NO}_{3}^{-\mathrm{a}}$ & $32.51 \pm 7.5 \mathrm{a}$ & $<0.001$ \\
\hline & & $\mathrm{NH}_{4}^{+\mathrm{b}}$ & $1.44 \pm 5.5 \mathrm{~b}$ & \\
\hline 0 & & $\mathrm{NO}_{3}^{-}$ & $0 \pm 0^{\mathrm{c}}$ & $<0.001(0$ vs. 0.3$)$ \\
\hline 0.3 & & & $38.09 \pm 12.6$ & $0.014(0.3$ vs. 3$)$ \\
\hline 3.0 & & & $59.43 \pm 7.4$ & \\
\hline 0 & & $\mathrm{NH}_{4}^{+}$ & $0 \pm 0$ & 0.004 (0 vs. 3$)$ \\
\hline 0.3 & & & $0 \pm 0$ & $<0.001(0.3$ vs. 3$)$ \\
\hline 3.0 & & & $4.33 \pm 3.8$ & \\
\hline
\end{tabular}

${ }^{\mathrm{a}} \mathrm{NO}_{3}{ }^{-}$predominant $=95 \% \mathrm{NO}_{3}{ }^{-} / 5 \% \mathrm{NH}_{4}{ }^{+}$

${ }^{\mathrm{b}} \mathrm{NH}_{4}{ }^{+}$predominant $=25 \% \mathrm{NO}_{3}^{-} / 75 \% \mathrm{NH}_{4}^{+}$

${ }^{\mathrm{c}}$ Only the results of the $\mathrm{AMF} \times \mathrm{N}$ form treatments are presented averaged over the dates

\section{Plant growth and mineral nutrient uptake}

Inoculation with the low AMF amount of $0.3 \%$ resulted in lower bulb fresh and dry mass than those of non-inoculated plants (Table 2). The time of inoculation had no effect on bulb mass. Bulb mass at predominant $\mathrm{NO}_{3}{ }^{-}$compared with $\mathrm{NH}_{4}{ }^{+}$ supply was enhanced. Onion plants had the highest bulb fresh and dry mass $(49.9 \pm 7.1$ and $7.89 \pm 1.2 \mathrm{~g})$ with predominant $\mathrm{NO}_{3}{ }^{-}$. Dry matter of the bulbs was reduced at predominant $\mathrm{NH}_{4}{ }^{+}$versus predominant $\mathrm{NO}_{3}{ }^{-}$supply. Moreover, reduced dry matter content was observed in the AMF-inoculated bulbs in combination with predominant $\mathrm{NH}_{4}{ }^{+}$supply.

Mycorrhizal treatments resulted in a significant increase in nitrogen and potassium content in bulbs while the content of phosphorus was not significantly influenced (Table 3). The higher the inoculum amount the higher the nitrogen and potassium content. Predominant $\mathrm{NH}_{4}{ }^{+}$supply increased nitrogen and phosphorus content compared with predominant $\mathrm{NO}_{3}{ }^{-}$, whereas the highest potassium content was observed in bulbs treated with predominant $\mathrm{NO}_{3}{ }^{-}$and high inoculum. The time of inoculation did not affect nutrient content at all because biomass increased when inoculated at the second date but nutrient concentrations decreased significantly. In all other cases, when nutrient content increased, it was because of a gain in the nitrogen or phosphorus concentrations.

\section{Flavonol profile}

The general flavonol profile had the highest abundance of QDG (71.9 $\mu \mathrm{mol} \mathrm{g}^{-1} ; 67 \%$ of all flavonols), followed by QMG (33.6 $\mu \mathrm{mol} \mathrm{g}$; 30\%) and IMG (4.19 $\left.\mathrm{mmol} \mathrm{g}^{-1} ; 4 \%\right)$ (Table 4). None of the treatments changed the composition of the three flavonols significantly. All treatments, however, interactively affected QDG and QMG in onion bulbs. A significantly higher QDG concentration was found in bulbs inoculated with the high AMF amount at the second inoculation date in combination with predominant $\mathrm{NH}_{4}{ }^{+}$than for plants with the low AMF amount at the same date or with predominant $\mathrm{NO}_{3}{ }^{-}$at the first date or not inoculated. QMG in bulbs also from the second inoculation date treated with the high amount of AMF inoculum at predominant $\mathrm{NH}_{4}{ }^{+}$was significantly higher than the concentrations in bulbs from non- or low-inoculated plants at predominant $\mathrm{NH}_{4}{ }^{+}$or at predominant $\mathrm{NO}_{3}{ }^{-}$but only if inoculated before seeding. IMG was not affected by the inoculation date but was affected by the interaction of the amount of inoculum and nitrogen form. IMG increased significantly in inoculated versus non-inoculated plants at predominant $\mathrm{NH}_{4}{ }^{+}$supply, and also in the treatments with the low inoculum amount at predominant $\mathrm{NO}_{3}{ }^{-}$versus high or non-inoculated plants.

\section{CHS, FLS, and PAL gene expression}

In general, total abundance of all transcripts in inoculated plants was higher than in not inoculated plants, and it was higher at the second inoculation compared to the first inoculation date (Table 5). But no main factor influenced gene expression significantly (Table 5). CHS1 and FLS1 expressions were influenced by interactions between nitrogen form and amount of mycorrhizal inoculation, however, while PAL1 expression was affected by the interaction of all three factors. Transcript levels of the CHS1 gene were higher when inoculated than when not inoculated, but significantly so only with the low inoculum amount at predominant $\mathrm{NO}_{3}{ }^{-}$and the high inoculum amount at predominant $\mathrm{NH}_{4}{ }^{+}$supply independent of the date of inoculation. FLS1 expression was higher in all treatments compared with non-inoculated at predominant $\mathrm{NH}_{4}{ }^{+}$, also independent of the date of inoculation. The highest expression was also found with the low inoculum amount at predominant $\mathrm{NO}_{3}{ }^{-}$but it differed significantly only from the non-inoculated treatment at predominant $\mathrm{NH}_{4}{ }^{+}$. PAL1 gene expression was highest with the low inoculum amount at predominant $\mathrm{NO}_{3}{ }^{-}$after the first and second inoculation and at predominant $\mathrm{NH}_{4}{ }^{+}$after the second inoculation and after the first inoculation with the high inoculum amount. In general, 
Table 2 Effect of mycorrhizal inoculation (AMF), date of inoculation (days after seeding), and nitrogen $(\mathrm{N})$ form on fresh mass (FM), dry mass (DM), and dry matter content (DMC) of onion plants ( $c v$. Stuttgarter Riesen) analyzed after a growing period of 149 days in a three factorial ANOVA based on an orthogonal design with six replications. Means \pm standard deviation followed by the same letter do not differ significantly according to Duncan's multiple range test. Probability levels written in italics indicate significant differences at a significance level of $\alpha=0.05$

\begin{tabular}{|c|c|c|c|c|c|}
\hline $\operatorname{AMF}(v / v \%)$ & Date (days) & $\mathrm{N}$ form & $\mathrm{FM}\left(\mathrm{g}_{\text {plant }}{ }^{-1}\right)$ & DM (g plant $^{-1}$ ) & DMC (gkg-1) \\
\hline 0 & & & $45.7 \pm 8.5 \mathrm{a}$ & $6.84 \pm 1.7 \mathrm{a}$ & $14.8 \pm 1.2$ \\
\hline 0.3 & & & $40.6 \pm 9.6 \mathrm{~b}$ & $5.91 \pm 1.8 \mathrm{~b}$ & $14.4 \pm 1.8$ \\
\hline \multirow[t]{5}{*}{3.0} & & & $43.5 \pm 10.2 \mathrm{ab}$ & $6.43 \pm 2.0 \mathrm{ab}$ & $14.6 \pm 1.5$ \\
\hline & 0 & & $42.3 \pm 9.9$ & $6.22 \pm 1.9$ & $14.5 \pm 1.5$ \\
\hline & 65 & & $44.2 \pm 9.4$ & $6.57 \pm 1.8$ & $14.7 \pm 1.6$ \\
\hline & & $\mathrm{NO}_{3}^{-\mathrm{a}}$ & $49.9 \pm 7.1 \mathrm{a}$ & $7.89 \pm 1.2 \mathrm{a}$ & $15.8 \pm 0.64$ \\
\hline & & $\mathrm{NH}_{4}{ }^{+\mathrm{b}}$ & $36.7 \pm 6.9 \mathrm{~b}$ & $4.90 \pm 1.0 \mathrm{~b}$ & $13.4 \pm 1.2$ \\
\hline 0 & & $\mathrm{NO}_{3}^{-}$ & $51.4 \pm 6.1^{\mathrm{c}}$ & $8.07 \pm 1.3^{\mathrm{c}}$ & $15.0 \pm 0.79 \mathrm{a}^{\mathrm{c}}$ \\
\hline 0.3 & & & $46.8 \pm 8.3$ & $7.46 \pm 1.2$ & $16.0 \pm 0.61 \mathrm{a}$ \\
\hline 3.0 & & & $51.6 \pm 6.4$ & $8.18 \pm 1.2$ & $15.8 \pm 0.48 \mathrm{a}$ \\
\hline 0 & & $\mathrm{NH}_{4}^{+}$ & $40.4 \pm 7.2$ & $5.71 \pm 1.2$ & $14.0 \pm 0.91 b$ \\
\hline 0.3 & & & $34.4 \pm 6.7$ & $4.36 \pm 0.65$ & $12.8 \pm 1.2 \mathrm{c}$ \\
\hline 3.0 & & & $35.2 \pm 5.8$ & $4.63 \pm 0.55$ & $13.3 \pm 1.2 \mathrm{c}$ \\
\hline \multicolumn{3}{|c|}{ Source of variation } & \multicolumn{3}{|l|}{ Probability level } \\
\hline $\mathrm{AMF}$ & & & 0.044 & 0.014 & 0.364 \\
\hline Date & & & 0.253 & 0.175 & 0.252 \\
\hline $\mathrm{N}$ form & & & $<0.001$ & $<0.001$ & $<0.001$ \\
\hline $\mathrm{AMF} \times$ date & & & 0.492 & 0.448 & 0.505 \\
\hline $\mathrm{AMF} \times \mathrm{N}$ form & & & 0.336 & 0.108 & 0.010 \\
\hline Date $\times \mathrm{N}$ form & & & 0.502 & 0.550 & 0.617 \\
\hline $\mathrm{AMF} \times$ date $\times$ & $\mathrm{rm}$ & & 0.275 & 0.737 & 0.312 \\
\hline
\end{tabular}

total abundance of all transcripts at the second inoculation date was higher than at the first inoculation.

\section{Discussion}

\section{Mycorrhization, plant growth, and nutrient uptake}

Plant genetic characteristics as well as environmental factors related to the soil, such as properties, texture, soil $\mathrm{pH}$, and nutrient concentration and distribution, directly affect nutrient availability and indirectly soil microorganisms including AMF (Carrenho et al. 2007). AMF colonization is influenced by additional factors, such as plant species, inoculum density, inoculum type, root growth rates, root age, and colonization period (McGonigle 2001). Although Daft and Nicolson (1969) used different amounts of inocula of Endogone macrocarpa for tomato, they found a similar percentage root length colonized 84 days after inoculation. In contrast, our plants inoculated with high amounts of inoculum showed a higher percentage root length colonized at harvest than plants treated with low amounts of inoculum. This was the case also for the second inoculation that was followed by 84 days of subsequent growing period. It can be assumed that the inoculum potential and days until harvest were not sufficient for the low inoculum amount $(0.3 \%)$ to have attained asymptotic colonization (McGonigle 2001). In agreement with our results, an enhanced growth of tomato plants, e.g., larger leaves, was associated with an elevated inoculum amount (Daft and Nicolson 1969). When our onion plants were inoculated 65 days after seeding, mycorrhization occurred, but a high amount of inoculum did not colonize significantly more roots than the low amount. Besides the reasons mentioned previously, this could also be because of other factors, such as (i) a high portion of old roots with few root tips as a primary entrance for the fungi (Smith and Walker 1981), (ii) effective "dilution" of inoculum at the second inoculation date across an already established a root system (Tawaraya et al. 1999), (iii) plant needs of assimilates obtained from photosynthesis to attain a high potential growth rate and to store for bulb formation, and (iv) competition among plants grown together in one pot (Hodge 2009). Moreover, AMF colonization decreased with predominant $\mathrm{NH}_{4}{ }^{+}$supply. Nitrogen form can affect AMF colonization by modifying the soil $\mathrm{pH}$ (Perner et al. 2008). Nitrate assimilation is known to be a protonconsuming process while $\mathrm{NH}_{4}{ }^{+}$assimilation is considered a proton-producing process. Predominant $\mathrm{NH}_{4}{ }^{+}$causes acidification of the rhizosphere resulting in slower root penetration 
Table 3 Effect of mycorrhizal inoculation (AMF), date of inoculation (days after seeding) and nitrogen $(\mathrm{N})$ form on nitrogen, phosphor $(\mathrm{P})$, and potassium $(\mathrm{K})$ content $(\%$ in the dry mass of onion bulbs $(\mathrm{cv}$. Stuttgarter Riesen) analyzed after a growing period of 149 days in a three factorial

\begin{tabular}{|c|c|c|c|c|c|c|c|c|}
\hline $\begin{array}{l}\mathrm{AMF} \\
(v / v \%)\end{array}$ & $\begin{array}{l}\text { Date } \\
\text { (days) }\end{array}$ & $\mathrm{N}$ form & $\begin{array}{l}\mathrm{N} \\
\left(\mathrm{mg} \mathrm{g}^{-1}\right)\end{array}$ & $\begin{array}{l}\mathrm{N} \\
\left(\mathrm{g}_{\text {plant }}^{-1}\right)\end{array}$ & $\begin{array}{l}\mathrm{P} \\
\left(\mathrm{mg} \mathrm{g}^{-1}\right)\end{array}$ & $\begin{array}{l}\mathrm{P} \\
\left(\mathrm{g} \mathrm{plant}^{-1}\right)\end{array}$ & $\begin{array}{l}\mathrm{K} \\
\left(\mathrm{mg} \mathrm{g}^{-1}\right)\end{array}$ & $\begin{array}{l}\mathrm{K} \\
\left(\mathrm{g}_{\text {plant }}{ }^{-1}\right)\end{array}$ \\
\hline 0 & & & $20.65 \pm 1.2 b$ & $1.24 \pm 0.28 \mathrm{~b}$ & $2.33 \pm 0.30 b$ & $0.15 \pm 0.02$ & $16.90 \pm 1.6$ & $0.99 \pm 0.29 \mathrm{~b}$ \\
\hline 0.3 & & & $21.62 \pm 1.3 \mathrm{a}$ & $1.33 \pm 0.32 \mathrm{ab}$ & $2.66 \pm 0.42 \mathrm{a}$ & $0.15 \pm 0.03$ & $17.00 \pm 1.58$ & $1.07 \pm 0.34 \mathrm{ab}$ \\
\hline \multirow[t]{5}{*}{3.0} & & & $21.47 \pm 1.9 \mathrm{a}$ & $1.39 \pm 0.25 \mathrm{a}$ & $2.62 \pm 0.41 \mathrm{a}$ & $0.15 \pm 0.04$ & $16.91 \pm 0.99$ & $1.15 \pm 0.26 \mathrm{a}$ \\
\hline & 0 & & $21.90 \pm 1.4 \mathrm{a}$ & $1.32 \pm 0.31$ & $2.65 \pm 0.42 \mathrm{a}$ & $0.16 \pm 0.04$ & $17.44 \pm 2.01 \mathrm{a}$ & $1.06 \pm 0.3$ \\
\hline & 65 & & $20.60 \pm 1.7 b$ & $1.32 \pm 0.26$ & $2.43 \pm 0.33 b$ & $0.15 \pm 0.03$ & $16.43 \pm 0.98 b$ & $1.08 \pm 0.3$ \\
\hline & & $\mathrm{NO}_{3}^{-\mathrm{a}}$ & $19.72 \pm 1.5 b$ & $1.11 \pm 0.19 b$ & $2.37 \pm 0.33 b$ & $0.13 \pm 0.02$ & $16.99 \pm 1.10$ & $1.33 \pm 0.18 \mathrm{a}$ \\
\hline & & $\mathrm{NH}_{4}^{+\mathrm{b}}$ & $22.77 \pm 1.7 \mathrm{a}$ & $1.54 \pm 0.19 \mathrm{a}$ & $2.70 \pm 0.40 \mathrm{a}$ & $0.18 \pm 0.02$ & $16.88 \pm 1.78$ & $0.82 \pm 0.14 b$ \\
\hline 0 & 0 & $\mathrm{NO}_{3}^{-}$ & $20.30 \pm 1.3 \mathrm{cde}$ & $1.50 \pm 0.17^{\mathrm{c}}$ & $2.33 \pm 0.22 b c$ & $0.17 \pm 0.015 b^{c)}$ & $17.66 \pm 1.36$ & $1.30 \pm 0.13^{\mathrm{c}}$ \\
\hline 0.3 & & & $20.20 \pm 1.9 \mathrm{def}$ & $1.47 \pm 0.19$ & $2.45 \pm 0.36 b c$ & $0.18 \pm 0.02 \mathrm{ab}$ & $17.0 \pm 0.89$ & $1.24 \pm 0.19$ \\
\hline 3.0 & & & $20.50 \pm 1.7 \mathrm{cde}$ & $1.61 \pm 0.19$ & $2.66 \pm 0.29 \mathrm{ab}$ & $0.19 \pm 0.029 \mathrm{a}$ & $16.66 \pm 1.21$ & $1.38 \pm 0.19$ \\
\hline 0 & 0 & $\mathrm{NH}_{4}^{+}$ & $22.16 \pm 1.1 \mathrm{bc}$ & $1.23 \pm 0.23$ & $2.48 \pm 0.23 b c$ & $0.12 \pm 0.014 \mathrm{c}$ & $17.16 \pm 1.72$ & $0.93 \pm 0.17$ \\
\hline 0.3 & & & $24.66 \pm 1.9 \mathrm{a}$ & $1.11 \pm 0.13$ & $3.02 \pm 0.39 \mathrm{a}$ & $0.13 \pm 0.024 \mathrm{c}$ & $18.16 \pm 1.47$ & $0.75 \pm 0.08$ \\
\hline 3.0 & & & $23.33 \pm 1.3 \mathrm{ab}$ & $1.17 \pm 0.13$ & $2.95 \pm 0.26 \mathrm{a}$ & $0.13 \pm 0.019 \mathrm{c}$ & $17.66 \pm 0.81$ & $0.77 \pm 0.11$ \\
\hline $\begin{array}{l}0 \\
0.3\end{array}$ & 65 & $\mathrm{NO}_{3}^{-}$ & $\begin{array}{l}18.60 \pm 1.2 \mathrm{f} \\
19.50 \pm 1.5 \mathrm{ef}\end{array}$ & & $\begin{array}{l}2.12 \pm 0.36 \mathrm{c} \\
2.51 \pm 0.31 \mathrm{bc}\end{array}$ & & $\begin{array}{l}16.66 \pm 1.21 \\
16.33 \pm 1.03\end{array}$ & \\
\hline 3.0 & & & $19.0 \pm 0.89$ ef & & $2.16 \pm 0.12 \mathrm{c}$ & & $17.16 \pm 0.75$ & \\
\hline 0 & 65 & $\mathrm{NH}_{4}^{+}$ & $21.50 \pm 1.5 \mathrm{~b} b c d$ & & $2.41 \pm 0.27 \mathrm{bc}$ & & $16.0 \pm 1.67$ & \\
\hline 0.3 & & & $22.16 \pm 0.9 \mathrm{bc}$ & & $2.66 \pm 0.47 \mathrm{ab}$ & & $16.5 \pm 2.25$ & \\
\hline 3.0 & & & $22.83 \pm 1.7 b$ & & $2.70 \pm 0.48 a b$ & & $15.83 \pm 1.83$ & \\
\hline \multicolumn{3}{|c|}{ Source of variation } & Probability level & & & & & \\
\hline \multicolumn{3}{|l|}{ AMF } & 0.050 & 0.025 & 0.004 & 0.22 & 0.972 & 0.003 \\
\hline \multicolumn{3}{|l|}{ Date } & $<0.001$ & 0.963 & 0.01 & 0.305 & 0.006 & 0.682 \\
\hline \multicolumn{3}{|l|}{$\mathrm{N}$ form } & $<0.001$ & $<0.001$ & $<0.001$ & $<0.001$ & 0.765 & $<0.001$ \\
\hline \multicolumn{3}{|c|}{$\mathrm{AMF} \times$ date } & 0.854 & 0.437 & 0.410 & 0.113 & 0.928 & 0.258 \\
\hline \multicolumn{3}{|c|}{$\mathrm{AMF} \times \mathrm{N}$ form } & 0.368 & 0.105 & 0.652 & 0.050 & 0.275 & 0.154 \\
\hline \multicolumn{3}{|c|}{ Date $\times \mathrm{N}$ form } & 0.824 & 0.215 & 0.981 & 0.180 & 0.123 & 0.862 \\
\hline \multicolumn{3}{|c|}{$\mathrm{AMF} \times$ date $\times \mathrm{N}$ form } & 0.034 & 0.577 & 0.049 & 0.624 & 0.622 & 0.094 \\
\hline
\end{tabular}

${ }^{\mathrm{a}} \mathrm{NO}_{3}{ }^{-}$predominant $=95 \% \mathrm{NO}_{3}^{-} / 5 \% \mathrm{NH}_{4}^{+}$

${ }^{\mathrm{b}} \mathrm{NH}_{4}{ }^{+}$predominant $=25 \% \mathrm{NO}_{3}{ }^{-} / 75 \% \mathrm{NH}_{4}{ }^{+}$

${ }^{\mathrm{c}}$ Only the results of the AMF $\times \mathrm{N}$ form interaction are presented averaged over the dates

and low AMF colonization in consequence (Graw 1979; Mengel and Kirkby 2001; Shen et al. 2005). Plant growth decreased with predominant $\mathrm{NH}_{4}{ }^{+}$supply as well, which is in agreement with previous findings (Perner et al. 2008). Another reason for the decreased bulb growth and low dry matter content at predominant $\mathrm{NH}_{4}{ }^{+}$supply could be a reduced activity of $\mathrm{NO}_{3}{ }^{-}$reductase in the leaves in response to $\mathrm{NH}_{4}{ }^{+}$accumulation (Jalloh et al. 2009). The depressive effect of $\mathrm{NH}_{4}{ }^{+}$on $\mathrm{NO}_{3}{ }^{-}$reductase activity is associated with $\mathrm{NH}_{4}{ }^{+}$ accumulation and $\mathrm{pH}$ decrease (Marschner 2012).

All pots in our experiment were provided with sufficient nutrients and no deficiency was observed. Nevertheless, in our experiment AMF stimulated total nutrient uptake (nitrogen and potassium) and also increased nutrient concentrations
ANOVA based on an orthogonal design with six replications. Means \pm standard deviation followed by the same letter do not differ significantly according to Duncan's multiple range test. Probability levels written in italics indicate significant differences at a significance level of $\alpha=0.05$ 
Table 4 Effect of mycorrhizal inoculation (AMF), date of inoculation (days after seeding), and nitrogen $(\mathrm{N})$ form on the most important flavonols in bulbs of onion plants $(c v$. Stuttgarter Riesen) in a three-factorial ANOVA based on an orthogonal design with six replications. Means \pm standard deviation followed by the same letter do not differ significantly according to Duncan's multiple range test. Probability levels written in italics indicate significant differences at a significance level of $\alpha=0.05$

\begin{tabular}{|c|c|c|c|c|c|}
\hline $\operatorname{AMF}(v / v \%)$ & $\begin{array}{l}\text { Date } \\
\text { (days) }\end{array}$ & $\mathrm{N}$ form & $\mathrm{QDG}^{\mathrm{c}}\left(\mu \mathrm{mol} \mathrm{g}^{-1}\right)$ & $\mathrm{QMG}^{\mathrm{d}}\left(\mu \mathrm{mol} \mathrm{g}{ }^{-1}\right)$ & $\mathrm{IMG}^{\mathrm{e}}\left(\mu \mathrm{mol} \mathrm{g}{ }^{-1}\right)$ \\
\hline \multicolumn{3}{|l|}{0} & $69.1 \pm 17.1$ & $30.9 \pm 11.2$ & $4.20 \pm 1.3$ \\
\hline \multicolumn{3}{|l|}{0.3} & $67.4 \pm 22.7$ & $29.4 \pm 11.0$ & $3.90 \pm 1.8$ \\
\hline \multirow[t]{5}{*}{3.0} & & & $79.1 \pm 32.0$ & $40.9 \pm 16.8$ & $4.40 \pm 2.2$ \\
\hline & 0 & & $65.9 \pm 19.1$ & $30.2 \pm 11.4$ & $4.23 \pm 1.8$ \\
\hline & 65 & & $77.9 \pm 27.7$ & $37.0 \pm 14.9$ & $4.15 \pm 1.8$ \\
\hline & & $\mathrm{NO}_{3}^{-\mathrm{a}}$ & $69.5 \pm 24.8$ & $33.4 \pm 14.0$ & $3.67 \pm 1.6$ \\
\hline & & $\mathrm{NH}_{4}^{+\mathrm{b}}$ & $74.3 \pm 24.2$ & $33.7 \pm 13.7$ & $4.51 \pm 1.9$ \\
\hline 0 & 0 & $\mathrm{NO}_{3}^{-}$ & $62.4 \pm 18.7 \mathrm{bc}$ & $30.7 \pm 8.8 \mathrm{bc}$ & $3.72 \pm 1.4 b c^{f}$ \\
\hline \multicolumn{3}{|l|}{0.3} & $51.9 \pm 8.27 \mathrm{c}$ & $21.0 \pm 5.19 \mathrm{c}$ & $5.05 \pm 2.2 \mathrm{a}$ \\
\hline \multicolumn{3}{|l|}{3.0} & $71.4 \pm 34.4 \mathrm{abc}$ & $38.3 \pm 12.3 \mathrm{abc}$ & $3.43 \pm 1.6 \mathrm{~d}$ \\
\hline 0 & 0 & $\mathrm{NH}_{4}^{+}$ & $66.6 \pm 15.0 \mathrm{bc}$ & $26.6 \pm 10.8 \mathrm{bc}$ & $3.42 \pm 1.1 \mathrm{~d}$ \\
\hline \multicolumn{3}{|l|}{0.3} & $69.0 \pm 22.9 \mathrm{abc}$ & $31.2 \pm 19.7 \mathrm{bc}$ & $4.38 \pm 1.4 \mathrm{~b}$ \\
\hline \multicolumn{3}{|l|}{3.0} & $74.1 \pm 25.3 \mathrm{abc}$ & $33.0 \pm 12.1 \mathrm{bc}$ & $4.64 \pm 1.9 \mathrm{ab}$ \\
\hline \multicolumn{3}{|l|}{$\begin{array}{l}0 \\
0.3\end{array}$} & $\begin{array}{l}74.1 \pm 16.2 \mathrm{abc} \\
85.5 \pm 21.6 \mathrm{ab}\end{array}$ & $\begin{array}{l}33.8 \pm 17.8 \mathrm{bc} \\
37.5 \pm 12.4 \mathrm{abc}\end{array}$ & \\
\hline \multicolumn{3}{|l|}{3.0} & $71.7 \pm 24.6 \mathrm{abc}$ & $39.3 \pm 13.1 \mathrm{ab}$ & \\
\hline 0 & 65 & $\mathrm{NH}_{4}^{+}$ & $73.4 \pm 7.19 \mathrm{abc}$ & $32.5 \pm 5.42 \mathrm{bc}$ & \\
\hline \multicolumn{3}{|l|}{0.3} & $63.2 \pm 26.9 \mathrm{bc}$ & $27.8 \pm 7.44 \mathrm{bc}$ & \\
\hline \multicolumn{3}{|c|}{3.0} & $99.4 \pm 37.6 \mathrm{a}$ & $50.9 \pm 18.4 \mathrm{a}$ & \\
\hline \multicolumn{3}{|c|}{ Source of variation } & Probability level & & \\
\hline \multicolumn{3}{|c|}{$\mathrm{AMF}$} & 0.031 & 0.009 & 0.725 \\
\hline \multicolumn{3}{|l|}{ Date } & 0.033 & 0.025 & 0.859 \\
\hline \multicolumn{3}{|l|}{$\mathrm{N}$ form } & 0.382 & 0.940 & 0.153 \\
\hline \multicolumn{3}{|l|}{$\mathrm{AMF} \times$ date } & 0.934 & 0.804 & 0.856 \\
\hline \multicolumn{3}{|l|}{$\mathrm{AMF} \times \mathrm{N}$ form } & 0.400 & 0.742 & 0.042 \\
\hline \multicolumn{3}{|c|}{ Date $\times \mathrm{N}$ form } & 0.561 & 0.984 & 0.786 \\
\hline \multicolumn{3}{|c|}{$\mathrm{AMF} \times$ date $\times \mathrm{N}$ form } & 0.044 & 0.048 & 0.129 \\
\hline
\end{tabular}

${ }^{\mathrm{a}} \mathrm{NO}_{3}{ }^{-}$predominant $=95 \% \mathrm{NO}_{3}{ }^{-} / 5 \% \mathrm{NH}_{4}{ }^{+}$

${ }^{\mathrm{b}} \mathrm{NH}_{4}{ }^{+}$predominant $=25 \% \mathrm{NO}_{3}{ }^{-} / 75 \% \mathrm{NH}_{4}{ }^{+}$

${ }^{\mathrm{c}} \mathrm{QDG}=$ quercetin-3,4'-di- $O-\beta$-D-glucoside

${ }^{\mathrm{d}} \mathrm{QMG}=$ quercetin-4'- $O-\beta$-D-glucoside

${ }^{\mathrm{e}} \mathrm{IMG}=$ isorhamnetin-4'-O- $\beta$-D-glucoside

${ }^{\mathrm{f}}$ Only the significant results of the AMF $\times \mathrm{N}$ form interaction are presented averaged over the dates
Milford and Johnston 2007). Although, phosphorus concentration increased at predominant $\mathrm{NH}_{4}{ }^{+}$supply, higher phosphorus content in plants inoculated with a high amount of inoculum together with predominant $\mathrm{NO}_{3}{ }^{-}$fertilization can be attributed to high root colonization leading to both enhanced growth and $\mathrm{NO}_{3}{ }^{-}$uptake.

\section{Flavonols, $P A L, C H S$, and $F L S$ gene expression}

In the present study, the composition and concentrations of the major onion flavonols, namely QDG, QMG, and IMG, are in accordance with the findings of other authors (Price and Rhodes 1997; Marotti and Piccaglia 2002; Mollavali et al. 2016). Similar to those studies, QDG concentration in our results was about twofold higher than QMG concentration, and IMG at about $4 \%$ amounted to the smallest portion of the total flavonol content. Interestingly and in contrast to the data of others (Perner et al. 2008; Fallovo et al. 2011; Osuagwu and Edeoga 2012; Zaghdoud et al. 2016), the two nitrogen forms solely did not affect flavonol concentration in our experiment but did so in interaction with AMF inoculation, confirming the importance of the environmental conditions for plant nutrition. Results in the literature are contradictory. On one hand, if the competition between polyphenolic compounds and protein biosynthesis is decreased, which can be caused by a predominant $\mathrm{NH}_{4}{ }^{+}$supply also possibly resulting in cell toxicity, a higher concentration of flavonols is expected (Ibrahim et al. 2012; Zaghdoud et al. 2016). On the 
Table 5 Effect of mycorrhizal inoculation (AMF), date of inoculation (days after seeding), and nitrogen $(\mathrm{N})$ form on chalcone synthase (CHS1), flavonol synthase (FLSI), and phenylalanine ammonia lyase (PAL1) gene expression (relative based on CT values) of onion bulbs ( $c v$. Stuttgarter Riesen) in a threefactorial ANOVA based on an orthogonal design with three replications. Values represent gene transcript abundance of $\mathrm{CHSI}$, $F L S 1$, and $P A L 1$ genes normalized to the reference gene $A L L$ ITS1 derived of three independent repetitions. Means \pm standard deviation followed by the same letter do not differ significantly according to Duncan's multiple range test. Probability levels written in italics indicate significant differences at a significance level of $\alpha=0.05$

\begin{tabular}{|c|c|c|c|c|c|}
\hline $\operatorname{AMF}(v / v \%)$ & Date (days) & $\mathrm{N}$ form & CHS1 & $F L S 1$ & PAL1 \\
\hline \multicolumn{3}{|l|}{0} & $2.83 \pm 0.94$ & $3.83 \pm 1.79$ & $2.43 \pm 0.98$ \\
\hline \multicolumn{3}{|l|}{0.3} & $3.61 \pm 1.06$ & $4.54 \pm 2.07$ & $2.89 \pm 1.76$ \\
\hline \multirow[t]{5}{*}{3.0} & & & $2.95 \pm 1.37$ & $4.05 \pm 1.23$ & $2.44 \pm 1.33$ \\
\hline & 0 & & $2.76 \pm 1.41$ & $3.96 \pm 2.01$ & $2.21 \pm 1.16$ \\
\hline & 65 & & $3.51 \pm 1.6$ & $4.32 \pm 1.69$ & $2.97 \pm 1.26$ \\
\hline & & $\mathrm{NO}_{3}^{-\mathrm{a}}$ & $3.32 \pm 1.26$ & $4.51 \pm 1.67$ & $2.65 \pm 1.22$ \\
\hline & & $\mathrm{NH}_{4}^{+\mathrm{b}}$ & $2.95 \pm 1.32$ & $3.78 \pm 1.69$ & $2.53 \pm 1.23$ \\
\hline 0 & 0 & $\mathrm{NO}_{3}^{-}$ & $2.73 \pm 1.2 b^{c}$ & $4.86 \pm 1.09 \mathrm{ab}^{\mathrm{c}}$ & $2.09 \pm 0.93 \mathrm{~b}$ \\
\hline \multicolumn{3}{|l|}{0.3} & $4.56 \pm 0.71 \mathrm{a}$ & $5.24 \pm 1.5 \mathrm{a}$ & $4.16 \pm 0.31 \mathrm{a}$ \\
\hline \multicolumn{3}{|l|}{3.0} & $2.65 \pm 0.7 \mathrm{~b}$ & $3.40 \pm 0.69 \mathrm{ab}$ & $2.09 \pm 0.68 \mathrm{~b}$ \\
\hline 0 & 0 & $\mathrm{NH}_{4}^{+}$ & $2.92 \pm 0.44 \mathrm{~b}$ & $2.81 \pm 0.43 \mathrm{~b}$ & $2.38 \pm 0.71 \mathrm{~b}$ \\
\hline \multicolumn{3}{|l|}{0.3} & $2.67 \pm 1.68 \mathrm{~b}$ & $3.85 \pm 1.36 \mathrm{ab}$ & $-0.62 \pm 3.37 \mathrm{c}$ \\
\hline \multicolumn{3}{|l|}{3.0} & $3.26 \pm 1.84 \mathrm{ab}$ & $4.70 \pm 1.36 \mathrm{ab}$ & $3.15 \pm 2.09 \mathrm{ab}$ \\
\hline 0 & 65 & $\mathrm{NO}_{3}^{-}$ & & & $2.30 \pm 0.71 b$ \\
\hline \multicolumn{5}{|l|}{0.3} & $3.39 \pm 0.9 \mathrm{ab}$ \\
\hline \multicolumn{5}{|l|}{3.0} & $1.84 \pm 0.77 \mathrm{~b}$ \\
\hline & $\mathrm{NH}_{4}^{+}$ & & & $2.94 \pm 0.23 \mathrm{ab}$ \\
\hline 0.3 & & & & & $4.64 \pm 0.64 \mathrm{a}$ \\
\hline \multicolumn{5}{|l|}{3.0} & $2.69 \pm 1.68 b$ \\
\hline \multicolumn{3}{|c|}{ Source of variation } & Probability level & & \\
\hline \multicolumn{3}{|l|}{$\mathrm{AMF}$} & 0.237 & 0.528 & 0.710 \\
\hline \multicolumn{3}{|l|}{ Date } & 0.065 & 0.498 & 0.147 \\
\hline \multicolumn{3}{|l|}{$\mathrm{N}$ form } & 0.347 & 0.177 & 0.821 \\
\hline \multicolumn{3}{|l|}{$\mathrm{AMF} \times$ Date } & 0.454 & 0.165 & 0.126 \\
\hline \multicolumn{3}{|l|}{$\mathrm{AMF} \times \mathrm{N}$ form } & 0.035 & 0.030 & 0.092 \\
\hline \multicolumn{3}{|c|}{ Date $\times \mathrm{N}$ form } & 0.517 & 0.690 & 0.054 \\
\hline \multicolumn{3}{|c|}{$\mathrm{AMF} \times$ Date $\times \mathrm{N}$ form } & 0.063 & 0.202 & 0.039 \\
\hline
\end{tabular}

${ }^{\mathrm{a}} \mathrm{NO}_{3}{ }^{-}$predominant $=95 \% \mathrm{NO}_{3}{ }^{-} / 5 \% \mathrm{NH}_{4}{ }^{+}$

${ }^{\mathrm{b}} \mathrm{NH}_{4}{ }^{+}$predominant $=25 \% \mathrm{NO}_{3}^{-} / 75 \% \mathrm{NH}_{4}{ }^{+}$

${ }^{\mathrm{c}}$ Only the significant results of the AMF $\times \mathrm{N}$ form interaction are presented averaged over the dates other hand, an advantage of a $\mathrm{NO}_{3}{ }^{-}$over an $\mathrm{NH}_{4}{ }^{+}$supply led to increasing quercetin and isorhamnetin concentrations (Perner et al. 2008; Fallovo et al. 2011). In the experiments of Fallovo et al. (2011), flavonol concentration increases happened only when Brassica plants had insufficient light $\left(<5 \mathrm{~mol} \mathrm{~m}^{-2} \mathrm{~d}^{-1}\right)$. Under increased radiation, nitrogen forms did not affect flavonoids. Consequently, other limiting conditions in addition to low light, such as low nutrient supply (Koeslin-Findeklee et al. 2015), or low temperature (Watanabe and Ayugase 2015) may interact with the effect of nitrogen nutrition. In our study, onions likely had no nitrogen deficiency whatsoever because the tissue concentration of total nitrogen was comparable with data from Huett et al. (1997). Moreover, plants received a $75 \% \mathrm{NH}_{4}{ }^{+}$supply and were cultivated under high daily light levels of $29 \mathrm{~mol} \mathrm{~m}^{-2}$ and a suitable temperature of $21 / 17^{\circ} \mathrm{C}$ (day/night). This might explain the missing effect of the nitrogen form. We found no significant correlation between nitrogen tissue concentration and single or total flavonols (data not shown).

Flavonol concentration in our experiment did increase significantly as a result of a late AMF inoculation (65 days) with the high amount of inoculum (3\%) at predominant $\mathrm{NH}_{4}{ }^{+}$supply. This supports the hypothesis that AMF colonization during the early phase of the symbiosis may induce higher flavonol concentration as a defense response, as was described previously (Guo et al. 2006, 2007; Yao et al. 2007; Perner et al. 2008). Such defense reactions are mostly known from attacks of fungal pathogens (reviewed by Rao 1990; Steinkellner et al. 2007; Hassan and Mathesius 2011). Indeed, some flavonols act as regulatory signals for the susceptibility of roots to AMF at the beginning of formation of the symbiosis as has been shown for quercetin stimulating the hyphal growth of different AMF genera (Bécard et al. 1992). After the early stage of the symbiosis, however, fungi may 
favor a change of the concentrations of specific flavonols, although the flavonol composition in our data was not affected by colonization. These data reflect only one time point ( 7 days after the second inoculation) and, therefore, are not sufficient to support this inference. Nevertheless, flavonol concentration at harvest increased more after the second inoculation treatment than after inoculation at seeding. Mycorrhizal symbiosis can stimulate flavonol accumulation both to establish the symbiosis and as a consequence of biotic stress (Larose et al. 2002). The low amount of AMF inoculum used in our treatments does not seem to be sufficient to trigger a defense response. Besides, after the symbiosis is established for an extended time after inoculation, the production of flavonoids as phytoanticipines is no longer necessary (Slimestad et al. 2007). In contrast to quercetin, IMG concentration was not affected by AMF inoculation, as also was shown by Perner et al. (2008). Although the increase in flavonols is most intense with predominant $\mathrm{NH}_{4}{ }^{+}$fertilization, the effect seems to be somewhat temporary. The results regarding the interaction between the nitrogen form, AMF inoculation, and date of inoculation do not support our hypothesis that a predominant $\mathrm{NH}_{4}{ }^{+}$supply induces a persistent effect on flavonols.

$P A L$ previously was found to be highly regulated at the transcriptional level in response to nitrogen source and abiotic factors (Olsen et al. 2008). In the present study, PAL1 expression was higher with predominant $\mathrm{NH}_{4}{ }^{+}$than $\mathrm{NO}_{3}{ }^{-}$supply, which is in agreement with previous studies demonstrating that increased activity of $P A L$ in $\mathrm{NH}_{4}{ }^{+}$-induced tissue can be due to the secondary nitrogen assimilation pathway activation through phenylpropanoid metabolism (Singh et al. 1998, Mihaljević et al., 2011). Some studies have shown that high $\mathrm{C} / \mathrm{N}$ ratios resulted in an increase in the concentration of flavonols and also transcript levels of the flavonoid pathway genes (Martin et al. 2002, Wan et al. 2015). Increased PAL expression in our study could be a result of both higher $\mathrm{C} / \mathrm{N}$ ratio in AMF inoculated plants related to enhanced photosynthesis rate and reduced $\mathrm{C}$ allocation from the plant to the fungi due to the nitrogen supply (Miller et al. 2002, Blanke et al. 2005). Some authors observed high levels of $P A L$ and $C H S$ transcripts in roots colonized by AMF (Harrison and Dickson 1994; Manibhushan and Manian 1995; Bonanomi et al. 2001). Results of our study indicate that the expression of $C H S$ and $F L S$, two key enzymes in flavonoid biosynthesis (Petrussa et al. 2013), was induced in onion plants inoculated with a low amount of inoculum and supplied with predominant $\mathrm{NO}_{3}{ }^{-}$(Moche et al. 2010). This suggests that under certain conditions, mycorrhizal colonization has the potential to contribute to a persistent increase in flavonols. Moreover, the activity of enzymes involved in the flavonoid pathway may depend on the nitrogen source (Fujiwara et al. 2015). Bonanomi et al. (2001) discovered an induction of a CHS gene (Mt-CHS1) after inoculation of Medicago truncatula with Glomus intraradices. They measured the expression on several different days post inoculation $(5,10,15$, and $20 \mathrm{dpi})$. While the induction always was found at $5 \mathrm{dpi}$, it could not be detected continuously at the later dates, which is in agreement with other reported results (Volpin et al., 1995; Mohr et al. 1998). The authors concluded that the expression was particularly detectable at the stage of the first contact with G. intraradices. Our sampling date for the measurement of gene expressions was 7 days after the second inoculation, a similar period to those chosen by Bonanomi et al. (2001). Plants from the first inoculation had their first contact with AMF 65 days earlier, however, and our plant material was different as we used bulbs and the others roots which might explain why we did not find a significant expression pattern.

Data from the present study provide evidence that a predominant $\mathrm{NH}_{4}{ }^{+}$supply together with AMF inoculation can significantly increase the content of flavonols in onion bulbs. AMF inoculation may act as biotic stress in the early stage of the symbiosis. To confirm this indication, measurements of expressions of related genes have to be carried out through time (Bonanomi et al. 2001). Although our data indicate there might be a permanent increase in flavonols under certain conditions, an increase of defense-related flavonoids can hardly be expected once the symbiosis is established. Nevertheless, an increase of flavonols in connection with AMF inoculation persisted at least 84 days after our second inoculation treatment.

Acknowledgements This research was supported by the Federal Ministry of Food and Agriculture, by the State Ministries of Science, Research, and Culture Brandenburg and of Infrastructure and Agriculture Thuringia. The Iranian Ministry of Science, Research, and Technology supported the research of Mohanna Mollavali. The authors wish to express their thanks to Gundula Aust and Susanne Jeserigk (IGZ) for their valuable help in conducting and analyzing the experiments.

Open Access This article is distributed under the terms of the Creative Commons Attribution 4.0 International License (http:// creativecommons.org/licenses/by/4.0/), which permits unrestricted use, distribution, and reproduction in any medium, provided you give appropriate credit to the original author(s) and the source, provide a link to the Creative Commons license, and indicate if changes were made.

\section{References}

Augé RM, Moore JL (2005) Arbuscular mycorrhizal symbiosis and plant drought resistance. In: Mehrotra VS (ed) Mycorrhiza: role and applications. Allied Publishers Limited, New Delhi, pp 136-157

Awad MA, de Jager A (2002) Relationship between fruit nutrients and concentrations of flavonoids and chlorogenic acid in 'Elstar' apple skin. Sci Hortic 92:265-276

Bécard G, Douds DD, Pfeffer PE (1992) Extensive in vitro hyphal growth of vesicular-arbuscular mycorrhizal fungi in the presence of $\mathrm{CO} 2$ and flavonols. Appl Environ Microbiol 68:260-1264

Beesk N, Perner H, Schwarz D, George E, Kroh LW, Rohn S (2010) Distribution of quercetin-3,4'-O-diglucoside, quercetin-4'-Omonoglucoside, and quercetin in different parts of the onion bulb (Allium cepa L.) influenced by genotype. Food Chem 122:566-571 
Bi HH, Song YY, Zeng RS (2007) Biochemical and molecular responses of host plants to mycorrhizal infection and their roles in plant defence. Allelopath J 20:15-28

Bilyk A, Cooper PL, Sapers GM (1984) Varietal differences in distribution of quercetin and kaempferol in onion (Allium cepa $\mathrm{L}$.) tissue. $\mathrm{J}$ Agric Food Chem 2:274-276

Blanke V, Renker V, Wagner M, Füllner K, Held M, Kuhn AJ, Buscot F (2005) Nitrogen supply affects arbuscular mycorrhizal colonization of Artemisia vulgaris in a phosphate-polluted field site. New Phytol 166:981-992

Bonanomi A, Oetiker JH, Guggenheim R, Bollet T, Wiemken A, VogeliLange R (2001) Arbuscular mycorrhizas in mini-mycorrhizotrons: first contact of Medicago truncatula roots with Glomus intraradices induces chalcone synthase. New Phytol 150:573-582

Buer CS, Imin N, Djordjevic MA (2010) Flavonoids: new roles for old molecules. J Integr Plant Biol 52:96-111

Carrenho R, Trufem SFB, Bononi VLR, Silva ES (2007) The effect of different soil properties on arbuscular mycorrhizal colonization of peanuts, sorghum and maize. Acta Bot Bras 21:723-730

Charron G, Furlan V, Bernier-Cardou M, Doyon G (2001) Response of onion plants to arbuscular mycorrhiza. Effects of nitrogen fertilization on biomass and bulb firmness. Mycorrhiza 11:145-150

Chu EY (1999) The effects of arbuscular mycorrhizal fungi inoculation on Euterpe oleracea Mart. (açaí) seedlings. Pesq Agrop Brasileira 34:1018-1024

Crozier A, Lean MEJ, McDonald MS, Black C (1997) Quantitative analysis of the flavonoid content of commercial tomatoes, onions, lettuce, and celery. J Agric Food Chem 45:590-595

Daft MJ, Nicolson TH (1969) Effect of Endogone mycorrhiza on plant growth. III. Influence of inoculum concentration on growth and infection in tomato. New Phytol 68:953-963

Dao TTH, Linthorst HJM, Verpoorte R (2011) Chalcone synthase and its functions in plant resistance. Phytochem Rev 10:397-412

Devi MC, Reddy MN (2002) Phenolic acid metabolism of groundnut (Arachis hypogaea L.) plants inoculated with VAM fungus and Rhizobium. Plant Growth Regul 37:151-156

Fallovo C, Schreiner M, Schwarz D, Colla G, Krumbein A (2011) Phytochemical changes induced by different nitrogen supply forms and radiation levels in two leafy Brassica species. J Agric Food Chem 59:4198-4207

Fujiwara T, Kanesaki Y, Hirooka S, Era A, Sumiya N, Yoshikawa H, Tanaka K, Miyagishima Y (2015) A nitrogen source-dependent inducible and repressible gene expression system in the red alga Cyanidioschyzon merolae. Front Plant Sci 6:657

George E (2000) Nutrient uptake. In: Kapulnik Y, Douds DJ (eds) Arbuscular mycorrhizas: physiology and functions. Kluwer academic Publisher, Dordrecht, pp 307-343

Giovannetti M, Mosse B (1980) Evaluation of techniques for measuring vesicular arbuscular mycorrhizal infection in roots. New Phytol 84: 489-500

Graw D (1979) The influence of soil $\mathrm{pH}$ on the efficiency of vesiculararbuscular mycorrhiza. New Phytol 82:687-695

Griffiths G, Trueman L, Crowther T, Thomas B, Smith B (2002) Onions - a global benefit to health. Phytother Res 16:603-615

Guo T, Zhang J, Christie P, Li X (2006) Influence of nitrogen and sulfur fertilizers and inoculation with arbuscular mycorrhizal fungi on yield and pungency of spring onion. J Plant Nutr 29:1767-1778

Guo T, Zhang J, Christie P, Li X (2007) Pungency of spring onion as affected by inoculation with arbuscular mycorrhizal fungi and sulfur supply. J Plant Nutr 30:1023-1034

Hamilton JG, Zangerl AR, DeLucia EH, Berenbaum MR (2001) The carbonnutrient balance hypothesis: its rise and fall. Ecol Lett 4:86-95

Harrison MJ, Dixon RA (1994) Spatial patterns of expression of flavonoid/isoflavonoid pathway genes during interactions between roots of Medicago truncatula and the mycorrhizal fungus Glomus versiforme. Plant J 6:9-20
Hassan S, Mathesius U (2011) The role of flavonoids in root-rhizosphere signalling: opportunities and challenges for improving plant-microbe interactions. J Exp Bot 63:3429-3444

Herms DA, Matson WJ (1992) The dilemma of plants: to grow or defend. Q Rev Biol 67:283-335

Hoagland DR, Arnon DI (1938) The water culture method for growing plants without soil. California Agricultural Experiment Station Circulation, 347:32

Hodge A (2009) Root decisions. Plant Cell Environ 32:628-640

Huett DO, Maier NA, Sparrow LA, Pigott TJ (1997) Vegetables. In: Reuter DJ, Robinson JB, Coleman L (eds) Plant analysis: an interpration manual. CSIRO Publishing, Collingwood, pp 424-427

Ibrahim MH, Jaafar HZE, Rahmat A, Abdul Rahman Z (2012) Involvement of nitrogen on flavonoids, glutathione, anthocyanin, ascorbic acid and antioxidant activities of Malaysian medicinal plant Labisia pumila Blume (Kacip Fatimah). Int J Molec Sci 13:393-408

Jalloh MA, Chen J, Zhen F, Zhang G (2009) Effect of different N fertilizer forms on antioxidant capacity and grain yield of rice growing under Cd stress. J Hazard Mat 162:1081-1085

Janos DP, Schroeder MS, Schaffer B, Crane JH (2001) Inoculation with arbuscular mycorrhizal fungi enhances growth of Litchi chinensis Sonn. trees after propagation by air-layering. Plant Soil 233:85-94

Jing JY, Rui YK, Zhang FS, Rengel Z, Shen JB (2010) Localized application of phosphorus and ammonium improves growth of maize seedlings by stimulating root proliferation and rhizosphere acidification. Field Crop Res 119:355-364

Koske RE, Gemma JN (1989) A modified procedure for staining roots to detect VA mycorrhizas. Mycol Res 92:486-505

Koeslin-Findeklee F, Rizi VS, Becker MA, Parra-Londono S, Arif M, Balazadeh S, Mueller-Roeber B, Kunze R, Horst WJ (2015) Transcriptomic analysis of nitrogen starvation- and cultivarspecific leaf senescence in winter oilseed rape (Brassica napus L.) Plant Sci 233:174-188

Kristopher AB, Anderson AJ (1996) Defense-related transcript accumulation in Phaseolus vulgaris L. colonized by the arbuscular mycorrhizal fungus Glomus intraradices Schenck\& Smith. Plant Physiol 110:675-688

Larose G, Chênevert R, Moutoglis P, Gagne S, Piché Y, Vierheilig H (2002) Flavonoid levels in roots of Medicago sativa are modulated by the development stage of the symbiosis and the root colonizing arbuscular-mycorrhizal fungus. J Plant Physiol 159:1329-1339

Lea US, Slimestad R, Smedvig P, Lillo C (2007) Nitrogen deficiency enhances expression of specific MYB and bHLH transcription factors and accumulation of end products in the flavonoid pathway. Planta 225:1245-1253

Lenin M, Selvakumar G, Thamizhiniyan P, Rajendiran R (2010) Growth and biochemical changes of vegetable seedlings induced by arbuscular mycorrhizal fungus. J Exp Sci 1:27-31

Ling-Lee M, Chilvers GA, Ashford AE (1977) A histochemical study of phenolic materials in mycorrhizal and uninfected roots of Eucalyptus fastigata Dean\&Maid. New Phytol 78:313-328

Liu A, Hamal C, Elmi A, Costa C, Ma B, Smith DL (2002) Concentrations of $\mathrm{K}, \mathrm{Ca}$ and $\mathrm{Mg}$ in maize colonized by arbuscular mycorrhizal fungi under field conditions. Can J Soil Sci 82:271-278

Mandal SM, Chakraborty D, Dey S (2010) Phenolic acids act as signaling molecules in plant-microbe symbioses. Plant Sign Behav 5:359-368

Manibhushan RK, Manian S (1995) Changes in the phenol metabolism of rice cultivars with reference to nitrogen fertilization and sheath blight disease. Acta Phytopath Entom Hung 30:191-203

Marotti M, Piccaglia R (2002) Characterization of flavonoids in different cultivars of onion (Allium cepa L.) J Food Sci 67:1229-1232

Materska M (2008) Quercetin and its derivatives: chemical structure and bioactivity. Rev Pol J Food Nutr Sci 58:407-413

Marschner P (2012) Marschner's mineral nutrition of higher plants, 3rd ed. $651 \mathrm{pp}$ edn. Elsevier, Amsterdam 
Martin T, Oswald O, Graham IA (2002) Arabidopsis seedling growth, storage lipid mobilization, and photosynthetic gene expression are regulated by carbon:nitrogen availability. Plant Physiol 128:472-481

McGonigle TP (2001) On the use of non-linear regression with the logistic equation for changes with time of percentage root length colonized by arbuscular mycorrhizal fungi. Mycorrhiza 10:249-254

Mengel K, Kirkby EA (2001) Principles of plant nutrition, 5th edn. Kluwer, Dordrecht $849 \mathrm{pp}$

Mihaljević S, Radić S, Bauer N, Garić R, Mihaljević B, Horvat G, LeljakLevanić D, Jelaska S (2011) Ammonium related metabolic changes affect somatic embryogenesis in pumpkin (Cucurbita pepo L.) Plant Physiol 168:1943-1951

Milford GFJ, Johnston AE (2007) Potassium and nitrogen interactions in crop production. Proceedings 615 international fertilizers society, York

Miller RM, Miller SP, Jastrow JD, Rivetta CB (2002) Mycorrhizal mediated feedbacks influence net carbon gain and nutrient uptake in Andropogon gerardii. New Phytol 155:149-162

Moche M, Stremlau S, Hecht L, Gobel C, Feussner I, Stohr C (2010) Effect of nitrate supply and mycorrhizal inoculation on characteristics of tobacco root plasma membrane vesicles. Planta 231:425-436

Mohr U, Lange J, Boller T, Wiemken A, Vögeli-Lange R (1998) Plant defence genes are induced in the pathogenic interaction between bean roots and Fusarium solani, but not in the symbiotic interaction with the arbuscular mycorrhizal fungus Glomus mosseae. New Phytol 138:589-598

Mollavali M, Bolandnazar SA, Schwarz D, Rohn S, Riehle P, Zaare Nahandi F (2016) Flavonol glucoside and antioxidant enzyme biosynthesis affected by mycorrhizal fungi in various cultivars of onion (Allium cepa L.) J Agric Food Chem 64:71-77

Mozumder SN, Moniruzzaman M, Halim GMA (2007) Effect of N, K and $\mathrm{S}$ on the yield and storability of transplanted onion (Allium cepa L.) in the hilly region. J Agric Rural Dev 5:58-63

Nguyen PM, Niemeyer ED (2008) Effects of nitrogen fertilization on the phenolic composition and antioxidant properties of basil (Ocimum basilicum L.) J Agric Food Chem 56:8685-8691

Olsen KM, Lea US, Slimestad R, Verheul M, Lillo C (2008) Differential expression of the four Arabidopsis PAL genes; PAL1 and PAL2 have functional specialization in abiotic environmental triggered flavonoid synthesis. Plant Physiol 165:1491-1499

Olsson PA, Burleigh SH, van Aarle IM (2005) The influence of external nitrogen on carbon allocation to Glomus intraradices in monoxenic arbuscular mycorrhiza. New Phytol 168:677-686

Osuagwu GGE, Edeoga HO (2012) Effect of inorganic fertilizer application on the flavonoid, phenol and steroid content of the leaves of Ocimum gratissimum (L) and Gongeronema latifolium (Benth). Int J Med Arom Plants 2:254-262

Perner H, Schwarz D, Krumbein A, Li XL, George E (2007) Influence of nitrogen form and mycorrhizal colonization on growth and composition of Chinese bunching onion. J Plant Nutr Soil Sci 170:762-768

Perner H, Rohn S, Driemel G, Batt N, Schwarz D, Kroh LW, George E (2008) Effect of nitrogen forms, supply and mycorrhizal colonization on organosulfur and phenolic compounds in onions. J Agric Food Chem 56:3538-3545

Petrussa E, Braidot E, Zancani M, Peresson C, Bertolini A, Patui S, Vianello A (2013) Plant flavonoids - biosynthesis, transport and involvement in stress responses. Int J Molec Sci 14:14950-14973

Ponce MA, Scervino JM, Erra-Balsells R, Ocampo JA, Godeas AM (2004) Flavonoids from shoots and roots of Trifolium repens (white clover) grown in presence or absence of the arbuscular mycorrhizal fungus Glomus intraradices. Phytochemistry 65:1925-1930
Price KR, Bacon JR, Rhodes MJC (1997) Effect of storage and domestic processing on the content and composition of flavonol glucosides in onion (Allium cepa). J Agric Food Chem 45:938-942

Price KR, Rhodes MJC (1997) Analysis of the major flavonols glycosides present in four varieties of onion (Allium cepa) and changes in composition resulting from autolysis. J Sci Food Agric 74:331-339

Rao AS (1990) Root flavonoids. Bot Rev 56:1-84

Riehle P, Vollmer M, Rohn S (2013) Phenolic compounds in Cistus incanus herbal infusions - antioxidant capacity and thermal stability during the brewing process. Food Res Int 53:891-899

Rhodes MJC, Price KR (1996) Analytical problems in the study of flavonoid compounds in onions. Food Chem 57:113-117

Scheible W, Morcuende R, Czechowski T, Fritz C, Osuna D, PalaciosRojas N, Schindelasch D, Thimm O, Udvardi MK, Stitt M (2004) Genome-wide reprogramming of primary and secondary metabolism, protein synthesis, cellular growth processes, and the regulatory infrastructure of Arabidopsis in response to nitrogen. Plant Physiol 136:2483-2499

Shen J, Li H, Neumann G, Zhang F (2005) Nutrient uptake, cluster root formation and exudation of protons and citrate in Lupinus albus as affected by localized supply of phosphorus in a split-root system. Plant Sci 168:837-845

Singh S, Lewis NG, Towers GHN (1998) Nitrogen recycling during phenylpropanoid metabolism in sweet potato tubers. J Plant Physiol 153:316-323

Slimestad R, Fossen T, Vagen IM (2007) Onions: A source of unique dietary flavonoids. J Agric Food Chem 55:10067-10080

Smith SE, Walker NA (1981) A quantitative study of mycorrhizal infection in Trifolium: separate determination of the rates of infection and of mycelial growth. New Phytol 89:225-240

Stewart AJ, Chapman W, Jenkins GI, Graham I, Martin T, Crozier A (2001) The effect of nitrogen and phosphorus deficiency on flavonol accumulation in plant tissues. Plant Cell Environ 24:1189-1197

Steinkellner S, Lendzemo V, Langer I, Schweiger P, Khaosaad T, Toussaint JP, Vierheilig H (2007) Flavonoids and strigolactones in root exudates as signals in symbiotic and pathogenic plant-fungus interactions. Molecules 12:1290-1306

Strissel T, Halbwirth H, Hoyer U, Zistler C, Stich K, Treutter D (2005) Growth-promoting nitrogen nutrition affects flavonoid biosynthesis in young apple (Malus domestica Borkh.) leaves. Plant Biol 7:677685

Tawaraya K, Imai T, Wagatsuma T (1999) Importance of root length in mycorrhizal colonization of welsh onion. J Plant Nutr 22:589-596

Volpin H, Phillips DA, Okon Y, Kapulnik Y (1995) Suppression of an isoflavonoid phytoalexin defense response in mycorrhizal alfalfa roots. Plant Physiol 108:1449-1454

Wan H, Zhang J, Song T, Tian J, Yao Y (2015) Promotion of flavonoid biosynthesis in leaves and calli of ornamental crabapple (Malus sp.) by high carbon to nitrogen ratios. Front Plant Sci 6:673

Watanabe M, Ayugase J (2015) Effect of low temperature on flavonoids, oxygen radical absorbance capacity values and major components of winter sweet spinach (Spinacia oleracea L.) J Sci Food Agric 95: 2095-2104

Yao Q, Zhu HH, Zeng RS (2007) Role of phenolic compounds in plant defense: induced by arbuscular mycorrhizal fungi. Allelopath J 20: $1-14$

Zaghdoud C, Carvajal M, Moreno DA, Ferchichi A, Martínez-Ballesta MC (2016) Health-promoting compounds of broccoli (Brassica oleracea L. Var. italica) plants as affected by nitrogen fertilisation in projected future climatic change environments. J Sci Food Agric 96:392-403 